$$
\begin{aligned}
& S C-R-65-991 \\
& \text { Corf }-650915-2
\end{aligned}
$$

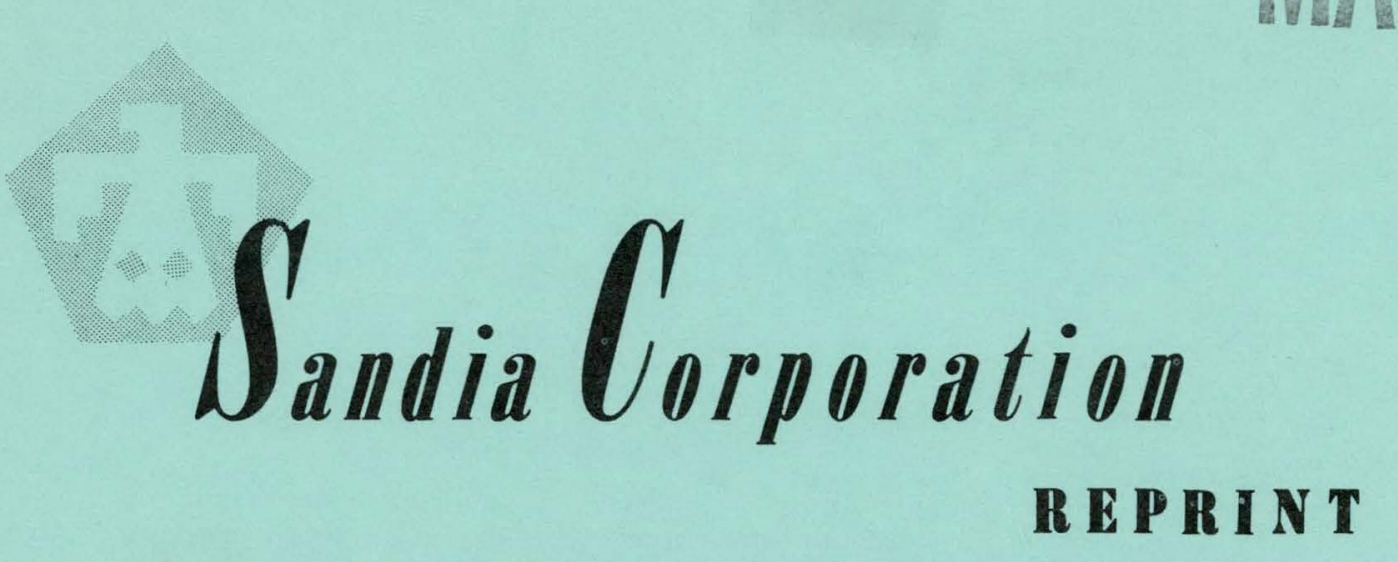

SAFETY AS A DESIGN FEATURE IN SYSTEMS

by

A D SWAIN

SEPTEMBER 1965 


\section{DISCLAIMER}

This report was prepared as an account of work sponsored by an agency of the United States Government. Neither the United States Government nor any agency Thereof, nor any of their employees, makes any warranty, express or implied, or assumes any legal liability or responsibility for the accuracy, completeness, or usefulness of any information, apparatus, product, or process disclosed, or represents that its use would not infringe privately owned rights. Reference herein to any specific commercial product, process, or service by trade name, trademark, manufacturer, or otherwise does not necessarily constitute or imply its endorsement, recommendation, or favoring by the United States Government or any agency thereof. The views and opinions of authors expressed herein do not necessarily state or reflect those of the United States Government or any agency thereof. 


\section{DISCLAIMER}

Portions of this document may be illegible in electronic image products. Images are produced from the best available original document. 
Presented at: Systems Fngineering Conference, McCormick Place, Chicago, Illinois, September 20-23, 1965.

Issued by Sandia Corporation,

a prime contractor to the

United States Atomic Energy Commission

\section{LE GAL NOTICE}

This report was prepared as an account of Government sponsored work. Neither the United States, nor the Commission, nor any person acting on behalf of the Commission:

A. Makes any warranty or representation, expressed or implied, with respect to the accuracy, completeness, or usefulness of the information contained in this report, or that the use of any information, apparatus, method, or process disclosed in this report may not infringe privately owned rights; or

B. Assumes any liabilities with respect to the use of, or for damages resulting from the use of any information, apparatus, method, or process disclosed in this report.

As used in the above, "person acting on behalf of the Commission" includes any employee or contractor of the Commission, or employee of such contractor, to the extent that such employee or contractor of the Commission, or employee of such contractor prepares, disseminates, or provides access to, any information pursuant to his employment or contract with the Commission, or his employment with such contractor. 


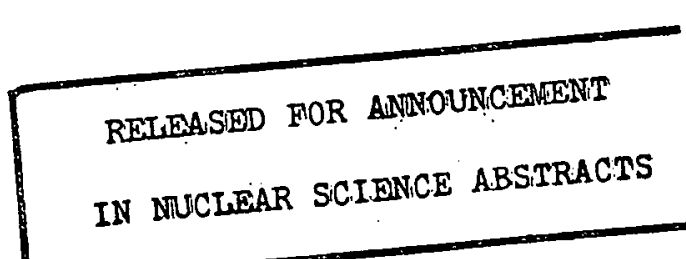

\section{SANDIA CORPORATION REPRINT}

\section{SAFETY AS A DESIGN FEATURE IN SYYSTEMS}

by

A. D. Swain

September 1965 
Designing safety features into systems (the situation approach) is a more effective way to reduce accidents than campaigning to make people more careful (the motivation approach). Hazards can be drastically and permanently reduced through design action in modifying the hazardous situation, whereas reduction through modifying people is limited and requires cunllu= uing reinforcement. Moreover, reinforcement gets exceedingly more difficult to achieve because of the human tendency to "tune out" stimuli a person comes to consider as noise. Sarety in syslems is a design problem, one to be resolved by objective engineering techniques.

This work was supported by the United States Atomic Energy Commission. 
TABJSE OF CONTENTS

\section{Page}

Introduction $\quad \ldots$

Safety Motivation Campaigns as Accident Reducers 1

Safety Education Versus Safety Motivetion I

Emphasis on Blame

Adaptation to Motivational Appeals

Evidence Related to Effectiveness of Safety Motivation

Campaigns

A Situation Approach to Reducing Accidents : 5

A Hypothetical Example 6

Explaining the Accident Reduction Program 6

$\begin{array}{ll}\text { Keep the Program a Worker Program } & 7\end{array}$

Importance of Near-Accident Data : 7

Encouraging Worker and Supervisor Cooperation 8

Sandia Corporation's Situation Approach. 8

An Accident Which Should Have Been Avoided $\quad \cdots \cdot \quad 9$

Accident Reduction as Part of a Larger Program to Reduce Errors 9

Conclusion $\quad$ : : $\quad$. 11 


\title{
SAFETY AS A DESIGN FEATURE IN SYSTEMS
}

\author{
Introduction
}

This paper makes two points. First, safety motivation campaigns are not considered to be notably effective in permanently reducing accidents in man-machine systems. Second, it is usually easier to change a situation which fosters accidents than to change an individual, and, moreover, changes to situations can be made permanent.

Sufety Mutivation Campaigns as Accilent Reducer's

Safety Education Versus Safety Motivation

In a report on "Reduction of Human Error in Industrial Production," * L. W. Rook pointed out that if the motivational level at an industrial plant can be considered to be at least average, only relatively minor improvements in workmanship can be effected by attempting to further increase the motivational level of the workers. It is only when this level is poor that efforts to increase motivation can be expected to improve workmanship significantly. Rook concludes that, "It is almost always worthwhile to expend effort in improving training, motivation, and attitudes until most of the work force is brought up in these factors to the general industrial average Level. However, it is doubtful whether further improvement in workmanship (reduction in errors) can be obtained economically by further training and motivational efforts until the production procedures have been analyzed in terms of the factors which affect human error."

Safety education campaigns often devote much of their effort to motivational appeals. To the extent that the content of such campaigns is primarily motivational, one can logically expect that Rook's conciusions regarding the effect of motivational efforts on workmanship should also apply to the effect of safety education campaigns on improving safe behavior. To the extent that the content of such campaigns is truly

* SCTM 93-62(14), Sandia Corporation, Albuquerque, New Mexico, June 1962. 
informative (that is, imparting safety information not known to the recipients), then one can logically expect that larger and more permanent modification of behavior should result. For example, if people are told by competent authorities (such as State Police) that driving in the Southwest region of the U. S. with headlamps "lit even on a bright, sunny day will significantly reduce the probability of a head-on collision, then it can be expected that a number of people will change their normal mode of driving behavior by permanently acquiring a new, safe driving habit. Note, however, that not all people who hear the message will react positively to it. This is a limitation even of a genuinely educational approach to safety.

In this paper, therefore, a distinction is made between safety education campaigns which do provide needed information and so-called safety education campaigns which emphasize signs, slogans, and other motivational gimicks. The se latter campaigns will be called "safety motivation campaigns" since their educational content is only incidental. The first part of this paper will describe some of the weaknesses of safety motivation campaigns. The second part describes a different approach to achieving a permanent reduction in accidents.

Emphasis on Blame

One of the limitations and pitfalls of the all-too-usual slogan-andsign approach to safety is that this approach is based on the premise that if people would only try harder to avoid accidents, then accidents would not happen. The reasoning is circular when carried to the extreme--if an individual had an accident, then; ipso facto, he did not try hard enough; he was careless, blameworthy. Ghiselli and Brown, two well-known investigators of accident causes, have noted that blaming the individual is missing the point on accidents. It does little good "to offer uncooperative behavior, inattention, and poor attitude as explanations of the causes of accidents. only in a superficial sense are these factors productive of accidents."

Consider, for example, an actual incident involving a crane operator who nearly killed a man. The operator was not highly experienced but he had operated the crane for about one month and had experienced no problems prior to the incident. The crane was located in an iron foundry and the operator's duties included loading large trays of small castings with the crane onto trucks. The truck driver typically stood on the bed of his truck and gave hand directions to the crane operator to facilitate placing the large tray onto the bed of the truck. In the incident. in question, the truck was a stake truck with the sides up. A large tray was to be loaded which used

*E. E. Ghiselli and C. W. Brown, Personnel and Industrial Psychology, N. Y.: McGraw-Hil1 Book Co., Inc., 1955, p. 363. 
up nearly all of the width of the truck bed. The truck driver guided the tray between the truck bed sides as he moved backwards towards the rear of the cab. When the leading edge of the tray was about two feet from the rear of the cab, the truck driver gave the signal to cease movement of the tray towards the cab. The driver was standing in the two feet gap between the tray and the cab. The crane operator meant to return the horizontal travel control to neutral; instead, he increased the rate of horizontal travel and the tray began to swing towards the truck driver. Instantly the crane operator realized his error and quickly reversed the control. But the inertia of the tray carried it forward and momentarily pinned the truck driver to the rear of the cab. The. truck driver was not injured although naturally upset at the incident. The incident was not officially reported since the crane operator feared for his job and the truck driver was sympathetic with this fear.

What caused this near-accident? Let us ignore the truck driver's contribution to the incident and consider only the crane operator. Was the crane operator careless? Was one month's experience not enough training? No doubt some would use this type of reasoning. But the major culprit was the situation itself as manifest in the design of the crane operating controls. To move the crane to the left the appropriate control had to be moved to the right, and vice versa. This is a classic example of a design which violates what is known as a populational stereotype, a natural and strong tendency for most people in a given population (location) to do something in a certain way. Training rarely, if ever, completely removes this tendency.

Thus, the above example clearly illustrates that the situation was. more directly related to the near-accident than the attitude or skill of the operator. Blaming him for this error would not likely have resulted in a permanent modification of his behavior even though he feared for his job.

Although not many examples of near-accidents or accidents are so clearcut, the principle still remains: blaming the individual is missing the point on accidents. As long ago as 1927, J. H. S. Bossard* remarked that carelessness is entirely too plausible an explanation of accidents. In his opinion, such an explanation usually is merely a smoke screen let down to hinder more detailed examination of factors which play a part in accidents.

Fage 439, Problems of Social Well-Being, Harper and Bros., N. Y., 1927. 
Adaptation to Motivational Appeals

Another limitation of the slogan approach is that it runs counter to human nature. Man has a psychological and physiological mechanism called adaptation. If he could not adapt to many different stimuli he would soon break down trying to respond to every sensory stimulus that impinges upon his sense organs. Man learns to tune out stimuli which are noise in the sense of conveying no information. Unfortunately; this mechanism of adaptation applies equelly well to worthwhile stimuli. Now, how is it possible to hold a man's interest month after month if THE approach to safety is the motivation campaign? I have been asked this question by safety experts who recognize and are concerned with this problem, and I am frank to say I don't know. It is simply characteristic of motivational appeals that their effectiveness wears out. People adapt to such campaigns. They gel luned oul.

Occasionally, however, a safety expert, with management's backing, will try to put some teeth in his campaign to make sure that people don't tune out safety motivation campaigns. Some years ago in one Midwest city, for example, the taxicab companies agreed that any cab driver having a frontend collision would be automatically fired. What happened? Very quickly it became apparent that the supply of unblemished taxicab drivers was diminishing rapidly. The result was that a taxicab driver fired from one company was immediately hired by another company. The rule stayed on the books, and as far as I know, may still be enforced. In any event, this example illustrates the absurdity of trying to prevent accidents merely by orders from management.

\section{Evidence Related to Effectiveness of Safety Motivation Campaigns}

Aside from the preceding difficulties and inconsistencies inherent in the slogan-and-sign approach to safety, have safety motivation campaigns been effective in modifying human behavior? What is the record?

A search in the literature of industrial psychology has failed to show a single controlled experiment on the real effectiveness of safety motivation campaigns. A quotation from a USAF report may be revealing:

Over the past fifty years there have been innumerable campaigns of safety education, using all the varied media of advertising and propaganda. That the compaigns have in some measure been fruitful is suggested by the general diminution of industrial accidents over the years, as indicated by the tables included in the introductory chapter of this report. Much of this reduction must, of course, be attributed to safety engineering, i.e., to reducing the hazards of the work situation. In fact, it is very difficult to isolate any part of the improvement in accident rates and say: "This is due to our safety education program." The possibility is not completely excluded that changes 
in the conditions of work together with changes in procedures for selecting and training personnel may account for all the gain. Controlled studies of the effects of safety education procedures appear to be largely nonexistent. Many articles state the value of the safety education program in a particular industry, but most of these are promotional articles offering little data on the relative effectiveness of a specific type of safety program.

I have painted a rather bleak picture of the effectiveness of the slogan approach to reducing accidents to a permanent minimum level. But although there is no real evidence of the effectiveness of safety motivation campaigns, I do not wish to imply that there is no place for posters, slogans, and other inspirational gimicks. I believe that most psychologists would agree with me in stating that it is well to be reminded now and then that one should be safety conscious. But with limited funds for accident reduction programs, it seems unwise to allocate most, or even a substantial amount, of these funds to safety motivation campaigns. A sounder approach would be to spend the money and effort to eliminate causes of accidents that can be eliminated permanently. The remainder of this paper describes such an approach.

\section{A Situation Approach to Reducing Accidents}

There is an approach to reducing accidents that is, or can be, free of emotion, that does not try to run counter to human nature, and which workers seem to find challenging and interesting. ** The situation approach involves first, providing appropriate recognition to workers for identifying accident-prone situations, and second, evaluation and correction of identified accident-prone situations. Although this scheme emphasizes changing the situation rather than the individual, it also should change the individual. In fact, it just cannot help changing the individual since it pays so much attention to his role as a productive worker. The situation approach should give him a new pride in his work and remove the onus of being held accountable for accidents that are made likely by the tools, equipment, and procedures which management has rurnished him.

\footnotetext{
*Thorndike, R. L., The Human Factor in Accidents with Special Reference to Aircraft Accidents, February 1951, Reprinted April 1962 by U. S. Department of Health, Education and Welfare, Department of Accident Prevention, p. 121.
}

This latter statement is based on an unpublished, informal study in $1961-62$ by $L$. W. Roak, who investigated the feasibility of getting foremen and workers at a production plant to report production errors. He found that when the situation approach was taken, foreman and worker cooperation was most gratifying. Furthermore, this study showed that most of the workers' errors were related to poor human engineering of equipment or procedures. 
In the human factors field, accident-prone situations (as I am using this term) are but one class of what are called error-likely situations. In applying the words accident proneness to situations rather than restricting them to individuals, I am intentionally broadening the meaning of this term. While on an intuitive basis, the concept of accident-prone individuals makes sense, it is "but one of the components of accident liability, [and] has been an overemphasized factor."* Well-controlled studies of so-called accident proneness in individuals show that the classical L-shaped curve which purports to demonstrate such accident proneness is, in fact due to two measurement conditions: "first, when the job is a relatively safe one and the average accident rate is low, and second, when accident records are collected for only a short period of time."** Furthermore, "the term accident proneness [as applied to individuals] has been used with so many different meanings that it can almost be considered useless."**

\section{An Hypothetical Example}

Explaining the Accident Reduction Program--Here is how the situation approach to reducing accidents could work in a factory. Management would make plain its belief that many accidents occur because the work situation (equipment, tools, or procedures) actually fosters errors despite the best possible planning and best intentions of the workers. Since it would be desirable to catch accidents before they happen, workers would be asked to help identify accident prone situations. Such situations would be fully described (perhaps with the foreman's help) and the possible consequences would be noted. Any suggestions on how to correct the accident-prone situation could be included, but the main idca would be to identify accidenl-prone situations--not provide solutions.

Management could start such a program by meeting with foremen and union representatives. Then a general meeting. (or series of meetings) of workers and management should be held. These meetings must be well publicized. An expert in behavioral science (preferably a human-factors engineer) might be called in to explain the new safety program, especially the point that workers are not necessarily to be blamed for all accidents. He could also explain how to recognize accident-prone situations, and provide examples in the context of jobs in the plant in question.

While the main reward for identifying accident-prone situations is obviously a safer and more productive plant for supervisors and employees,

Mintz, A. and Blum, M. I., "A Re-examination of the Accident Proneness Concept," Article 57 in Fleishman, E. A. (ed), Studies in Personnel and Industrial Psychology, Homewood, IIl.: The Dorsey Press, Inc., 1961.

**

Ghiselli and Brown op. cit., pp. 341-346. 
certain other rewards could be given. These rewards should be appropriate to the plant and the workers involved. (Cash awards are not necessarily the most effective. ${ }^{*}$ )

Keep the Program a Worker Program--To assure that the program remains a worker program, the foreman must pass on all suggestions that come to him. otherwise he might act as a censor and keep good information from reaching action levels of management. Foremen also should not be allowed to submit accident-prone situation reports unless done in association with a worker. This would serve two purposes. First, it would bring in the worker whose work station is involved, and he might have some good ideas. Second, it would keep some foremen from claiming credit for someone else's ideas, a not uncommon occurrence in employee suggestion programs.

As mentioned, the program should emphasize the 1dentification of accident-prone situations and at the same time encourage suggestions on how to correct the situation. It is very important not to laugh at or deride any ideas, no matter how ridiculous they seem. An unsympathetic attitude would only reinforce the all-too-usual worker suspicion of management-sponsored programs. All suggestions should be received and appropriately acknowledged. Only those with merit need be singled out for special attention:

Importance of Near-Accident Data--The situation approach to reducing accidents should emphasize the reporting of both accidents and near accidents. Everyone should be encouraged to report both of these in detail. The nearaccident data are especially important because, as noted, the rate of actual accidents, especially those resulting in personnel injury serious enough to result in lost time, is often too low to permit meaningful statistical comparisons. In the $1940^{\prime} \mathrm{s}$, Air Force investigators** began to rely heavily on near-accident data of aircrewmen because accident data were too few or incomplete. Once this was done, the Air Force began to find a pattern of equipment design features related to certain types of accidents. For example, it was found that pilots moving from one type of aircraft to another often grabbed the landing gear control when they wanted the flaps control, and vice versa. The position of these two controls were reversed on the two aircraft. Was the pilot to blame for the resulting accident because he was

Roth, H. F., "Does Higher Pay Bring Higher Productivity," Article 26 in Fleishman, E. A. (ed), Studies in Personnel and Industrial Psychology, Homewood, Ill.: The Dorsey Press, Inc., 1961.

**

Fitts, P. M., Psychological Research on Equipment Design, Army Air Force Aviation Psychology Program, Report 19, Washington, D. C., 1947. 
careless? There were a few who thought so. Fortunately, others took steps to change the situation--locations of flaps and landing gear controls were standardized and controls were shape coded.

Encouraging. Worker and Supervisor Cooperation--one goal of the situation approach recomended is to improve statistical techniques related to accidents. Workers could be motivated to report near-accidents and be truthful about accidents once the concept of blame is relegated to an insignificant role.

Another goal is to make people more accident-conscious by making it a game, albeit a serious game, to nip accidents in the bud. By people, I mean everyone involved--workers and supervisors and managers. Once the idea of the situation-caused accident is accepted, people are on the lookout for such situationo, and, incidentally tend to be less careless as well.

\section{Sandia Corporation's Situation Approach}

At Sandia Corporation the Safety Engineering Department's recently distributed "Recommended Safety Guides and Practices" begins with the premise that, "no man can be fully alert sixty seconds of every minute, sixty -minutes of every working hour all day long.". Thus, "accident prevention requires safety engineering to protect each man during the potentially fatal moment each day when his mind is diverted or simply wanders briefly from the task at hand."

The Safety Engineering Department urges management to "instigate an objective analysis and make a report of all the factors contributing to the accident, of when, how, where, and why it occurred." They also emphasize the need to report near accidents as well as actual accidents and injuries as the attached sample accident investigation report shows.

The above mentioned document shows photographs depicting the slow evolution of the lathe from 1900 to 1960. In the early lathe the flat belt drive, cone pully, and gears were all exposed and there were dangerously located controls. A picture of a 1930 lathe shows some improvements but still some accident-prone situations. Finally, the picture of a 1960 lathe illustrates a design where many of the hazards of earlier designs are eliminated. Now, this lathe evolution was no doubt in part brought about by the need to reduce accidents of lathe operators. The safety approach advocated in this paper. would place emphasis on identifying the need to change equipment design before an accident occurs.

*This approach is described in: Allison, W. W., "High Potential Accident Analysis," A.S.S.E. Journal, 1965, 10, 9-12. 
Report all neur-misses, unsafe practices, conditions, delayed treatment cases and accidents that did or could under slightly differént circunstunces potentially result in serious injury or damage.

DISTRIBUTION:

MANAGER, 3210

IST COPY - DIRECTOR OF RESPONSIGLE ORG.

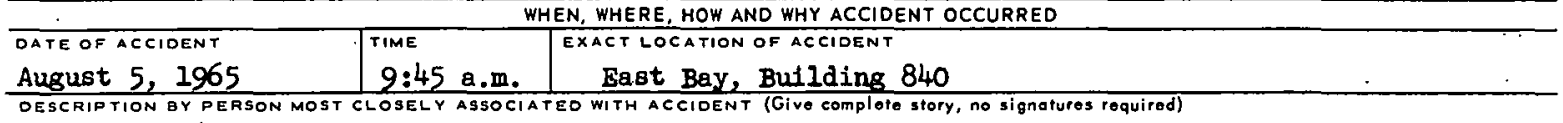

OESCRIPTION BY PERSON MOST CLOSELY ASSOCIATEO WITH ACCIOENT (Give eOmplote story, no signafures requirod)

I was operating three ton Pendant Push-Button bridge crane moving equipment in the East Bay when without any warning the bridge brake drum fell within inches of my head and struck the concrete floor.

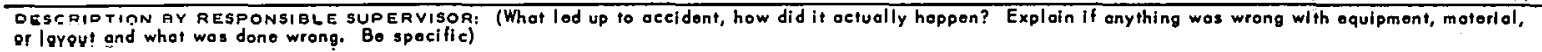

The metal brake drum weighing about four pounds was secured on the end of a shaft near the center of the outer edge of the bridge and was secured only by a single small set screw pressing against a small key.

Crane inspectors arè àware tnat inese wurk luuse and when thej find a loooc ono, thoy snctall a second set screw to lock the first and a new hole and set screw at a $90^{\circ}$ angle from the first one. This crane was inspected $3 / 1 / 65$.

WMAT HAS BEEN DONE TO CORRECT CONDITIONS CAUSING THE ACCIDENT:

Crane is being red-tagged until new brake drum with additional set screw $90^{\circ}$ from first Inserted into shaft.

(THIS IS AN ACTUAL NEAR-ACCIDENT--NAMES OF PEOPLE INVOLVED HAVE BEEN OMITTED HERE)

WHAT REMAINS TO BE DONE TO CORRECT SUCH CONDITIONS AND WHY

Install an additional set screw $90^{\circ}$ from first and ping shaft to allow securing of set screw onto shaft on all cranes. Specify same for new cranes. Also install bracket to prevent brake parts from falling.

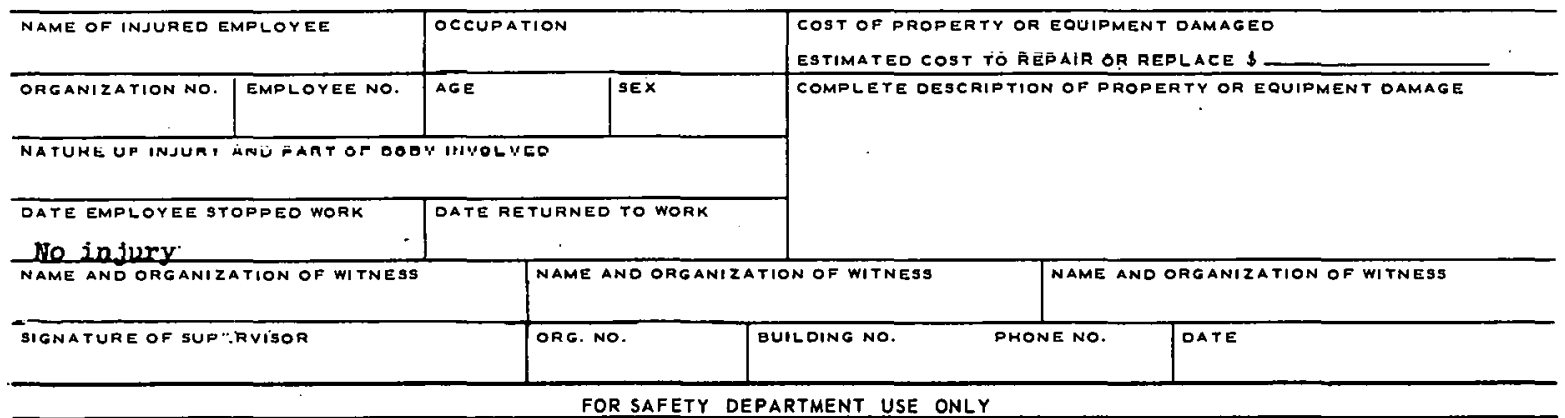

COMMENTS ON ADEQUACY OF CORRECTIVE ACTION TAKEN, OR PLANNED, INCLUOING PROGRESS ON PENDING ACTION FINAL COST DATA

Providing about a $\frac{1}{4}$ deep hole in the brake shaft and securing it $90^{\circ}$ from the key with a set screw and installing a simple bracket at end of brake on all such poorly designed crane brake shœs and other overhanging parts will prevent such high potential accidents that could cause fatal injuries. 
An Accident Which Should Have Been Avoided

Consider, for example, an accident-prone situation in a plant assembling anti-tank grenades during World War II: The only safing: device on these grenades was a safing pin inserted in a groove in the firing pin. If the pin was omitted, the grenade could explode when dropped on its nose. A woman at one work station performed several assembly operations on the grenade, including insertion of the safety pin. Since this was obviously a very important operation, the woman was exhorted to be careful, and, two inspectors were charged with verifying the presence of the critical part. But it was only a matter of time before. the next assembler in the line, also a woman, was killed when she dropped a grenade on its nose. Was 'she the victim of her fellow worker's carelessness? One could say so, but it would not solve the problem. Actually, the dead factory worker was the victim of an accident-prone situation, a production design which could have been avoided had management taken the situation approach to accident reduction.

The accident-prone situation was finally corrected--after the fatality. The correction was simple. The conveyer belt was changed so that the woman performing the critical assembly operation had to get all the pieces in place to be able to hang the grenade on a conveyer hook to send it to the next station. This corrective action emphasizes a fundamental principle of safety design: Make it physically necessary to follow the correct procedure or else one cannot proceed with the work.

Accident Reduction as Part of a Irarger Program to Reduce Errors

As mentioned, accident-prone situations can be classified as a special case of error-likely situations in which equipment, tools, fixtures and procedures foster human error. The situation approach to reducing accidents can also be applied to reducing most kinds of human errors. In describing an over-all error reduction program, L. W. Rook* says that, "...the most important goal of an error-reduction program [is] the inculcating of middle and upper management with the idea that management is itself responsible for a major part of the human error problem by failing to recognize the difference between HCE's [human caused errors] and SCE's [situation caused errors] and

* Rook, L. W., Motivation and Human Error. SC-TM-65-135, Sandia Corporation, Albuquerque, New Mexico, March 1965. 
by assuming that all or most of the problem derives from HCE's while rational consideration indicates exactly the reverse." He states that a new role for management could be to "assume its basic responsibility for creating SCE-free environments for workers," and that this could be done by "an all-out program of 'design for producibility," analogous to the "design for maintainability" program of electronic industries.

It seems reasonable that such a program, whether applied only to accident reduction or to the larger problem of industrial worker errors, should have a large payoff. The technical know-how (from engineering psychologists, human factors specialists, and industrial engineers) is readily available. The only need is to recognize the problem and put it in the proper perspective, namely, emphasis on the design of situations rather than the changing of individuals.

Conclusion

The situation approach either to reduction of accidents or errors in general has not, to my knowledge, been given a full-scale tryout in industry, although military services, especially the Air Force, do engineer systems for human use and conduct research in this field. The situation approach as described here and in Rook's 1965 report should work. It is psychologically sound; people are taken as they are, not as someone would like them to be. It recognizes that most errors in man-machine systems are caused by situations rather than by human perversity. In the situation approach, safety (and human errors) is a design problem in systems, one to be resolved by objective engineering and human engineering techniques. 